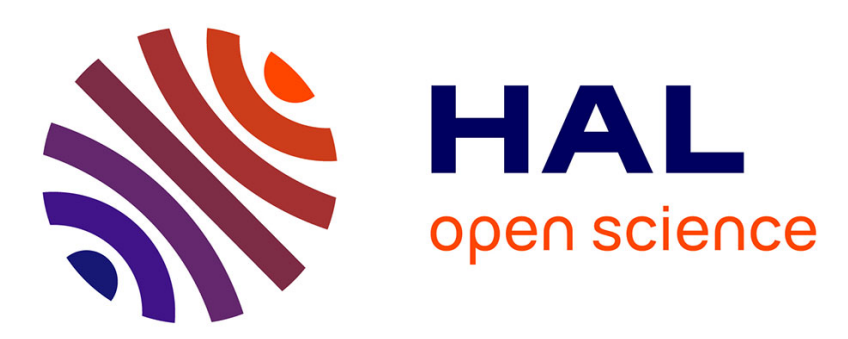

\title{
Changes in the chemical composition of alder, poplar and willow leaves during decomposition in a river Eric Chauvet
}

\section{To cite this version:}

Eric Chauvet. Changes in the chemical composition of alder, poplar and willow leaves during decomposition in a river. Hydrobiologia, 1987, vol. 148 ( $\mathrm{n}^{\circ}$ 1), pp. 35-44. 10.1007/BF00018164 . hal-01308110

\section{HAL Id: hal-01308110 https://hal.science/hal-01308110}

Submitted on 27 Apr 2016

HAL is a multi-disciplinary open access archive for the deposit and dissemination of scientific research documents, whether they are published or not. The documents may come from teaching and research institutions in France or abroad, or from public or private research centers.
L'archive ouverte pluridisciplinaire HAL, est destinée au dépôt et à la diffusion de documents scientifiques de niveau recherche, publiés ou non, émanant des établissements d'enseignement et de recherche français ou étrangers, des laboratoires publics ou privés. 


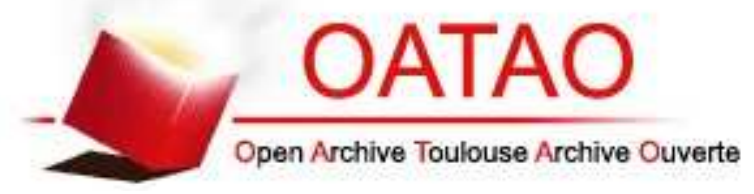

\section{Open Archive TOULOUSE Archive Ouverte (OATAO)}

OATAO is an open access repository that collects the work of Toulouse researchers and makes it freely available over the web where possible.

This is an author-deposited version published in : http://oatao.univ-toulouse.fr/ Eprints ID : 9648

To link to this article : DOI : 10.1007/BF00018164

URL : http://www.springerlink.com/index/10.1007/BF00018164

To cite this version : Chauvet, Eric Changes in the chemical composition of alder, poplar and willow leaves during decomposition in a river. (1987) Hydrobiologia, vol. 148 ( $\mathrm{n}^{\circ}$ 1). pp. 35-44. ISSN 0018-8158

Any correspondance concerning this service should be sent to the repository administrator: staff-oatao@ listes-diff.inp-toulouse.fr 


\title{
Changes in the chemical composition of alder, poplar and willow leaves during decomposition in a river
}

\author{
Eric Chauvet \\ Centre d'Ecologie des Ressources Renouvelables, 29, rue Jeanne Marvig, 31055 Toulouse Cedex - \\ France
}

Keywords: decomposition, river, leaves, Alnus glutinosa, Populus nigra, Salix alba

\begin{abstract}
(1) As there was a paucity of information on the aquatic decomposition of leaves of willow (Salix alba), poplar (Populus gr. nigra) and alder (Alnus glutinosa), the net-bag technique was used to study chemical changes in the leaves over a period of six months in the Garonne (France).

(2) The disappearance rates of foliar organic matter were about similar for the three species $(k=0.0065$ day $^{-1}$ for alder, $k=0.0054$ day $^{-1}$ for poplar and $k=0.0050$ day $^{-1}$ for willow). Changes in carbon amount were comparable to those of organic matter. Nitrogen and organic phosphorus accumulated during the first months of decomposition. The $\mathrm{C} / \mathrm{N}$ ratios of foliar matter changed in the same way in the three species, falling steeply for the first month, then levelling off. Amounts of sugar disappeared very rapidly, particularly for alder and willow. Cellulose concentrations were constant throughout the whole decomposition process whilst an increase in the amounts of lignin was observed during the first months; however the latter could be due to an interference by microbial compounds.

(3) The changes of some constituents, such as carbon, sugars and cellulose, were described with exponential or multiexponential models. Despite the very different initial ratios of $\mathrm{C} / \mathrm{N}$ and lignin/ $\mathrm{N}$, these changes associated with leaf decomposition were similar for the three species.
\end{abstract}

\section{Introduction}

During the last two decades, several authors have demonstrated the importance of allochthonous organic matter in rivers and that the functioning of ecosystems in forest streams is dependent on the considerable contribution of dead leaves coming from trees on the banks (Hynes, 1963; Minshall, 1967, 1968; Cummins, 1979; Vannote et al., 1980).

The decomposition processes of leaf litter in water have been studied by several authors who have recorded the influence of a number of factors on the kinetics of disappearance of organic matter, for example: leaf species (Petersen \& Cummins, 1974), the action of aquatic invertebrates (Kaushik \& Hynes, 1971; Sedell et al., 1975; Richard \& Moreau, 1982), bacterial and fungal colonization (Bärlocher \& Kendrick, 1974; Willoughby, 1974; Suberkropp \&
Klug, 1976), the nutrient concentrations in the water (Kaushik \& Hynes, 1971; Meyer \& Johnson, 1983) or the nature of the substratum (Reice, 1977, 1980). The $\mathrm{C} / \mathrm{N}$, and especially the lignin/ $\mathrm{N}$ ratios of plant matter are considered as good indicators of the decomposition kinetics (Triska et al., 1975; Godshalk \& Wetzel, 1978; Melillo et al., 1983).

Until recently, no data were available on the species belonging to South European riparian forests. This study addresses the aquatic degradation processes for leaves of alder (Alnus glutinosa Gaertn.), poplar (Populus gr. nigra) and willow (Salix alba L.). These species are found commonly on the borders of the Garonne and many Mediterranean rivers. This is the first study on leaf decomposition for Salix alba and the second study on $\mathrm{Al}$ nus glutinosa and Populus nigra (cf. Triska, 1970; Trémolières, 1979). This paper describes changes in 
chemical composition of these deciduous leaves during decomposition.

\section{Study area}

The decomposition experiments were carried out in a part of the Garonne river (South-Western France) which supplies a small hydro-electric works. The conditions of temperature, sediment quality, discharge variations and accessability to invertebrates are the same as in the main channel of the Garonne. Here the Garonne is 80 to $300 \mathrm{~m}$ wide (seventh order stream). The river is sinuous and presents calm zones alternating with shallow rapids. A few small wooded islands remain. The experimental station was $10 \mathrm{~km}$ downstream of the confluent of the Ariege. The average annual flow is $192 \mathrm{~m}^{3} \mathrm{~s}^{-1}$ (1941-81 period); the winter or spring floods frequently exceed $1000 \mathrm{~m}^{3} \mathrm{~s}^{-1}$ (daily average); in summer or early autumn, the rate of flow is in the range 40 to $50 \mathrm{~m}^{3} \mathrm{~s}^{-1}$.

The Garonne's banks are wooded (Salix alba) and sustain cultivated poplar stands (Populus gr. nigra) in numerous sites and alder woods (Alnus glutinosa); these three species are the most characteristic of the Garonne's riparian forest.

The river bottom consists of silt, sand and gravel. The experimental station is just upstream of the city of Toulouse and its factories. Thus, water quality is in no way affected by significant pollution sources. The waters are slightly alkaline $(\mathrm{pH}=8$, alkalinity $=120 \mathrm{mg} \mathrm{l}^{-1} \mathrm{HCO}_{3}^{-}$), and have a mean nitrate concentration of $0.7 \mathrm{mg} \mathrm{l}^{-1} \mathrm{NO}_{3}-\mathrm{N}$ and a mean phosphate concentration of $0.07 \mathrm{mg} \mathrm{l}^{-1}$ $\mathrm{PO}_{4}$-P. During the study, the water temperature varied between $6^{\circ} \mathrm{C}$ (December) and $15^{\circ} \mathrm{C}$ (June). Temperature reaches $23^{\circ} \mathrm{C}$ in summer and annual degree-days based on monthly measurements is 4820 for the $1983-1984$ period (A.F.B.A.G. data). ${ }^{a}$

\section{Material and methods}

The decomposition of leaf samples was measured in nylon net bags. This technique has been criticized because the mesh size limits the size of invertebrates involved (Petersen \& Cummins, 1974;

a Agence Financière de Bassin Adour-Garonne.
Sedell et al., 1975). As a sufficiently large mesh was used, invertebrates activity was minimally limited because the organisms involved are small in a large river. Mathews \& Kowalczewski (1969) showed that, in the river Thames, the kinetics of decomposition was not related to the net's mesh size. Also, Benfield et al. (1977), Meyer (1980) and Reice (1980) found the role of invertebrates to be unimportant in some streams. Moreover, as the purpose of this study was to consider particulate organic matter larger than $1-2 \mathrm{~mm}$, the net bag technique was deemed more appropriate.

Samples of recently fallen whole leaves $(5 \mathrm{~g})$ were air dried for a week and then placed in $20 \mathrm{~cm}$ long net bags with a mesh size $2 \mathrm{~mm}$ (ref. UGB Nytrel Ti 2000). These bags were attached to a string anchored to the bank, which kept them close to the river bed. They were immersed in the Garonne on 2 December, 1983. For each species (common alder, black poplar, white willow) three net bags were removed after 28, 59, 119 and 185 days of immersion. The samples extracted from the bags were air dried and placed in a drying oven at $50^{\circ} \mathrm{C}$ for three days. After weighing, they were ground and passed through a $1 \mathrm{~mm}$ sieve.

The sediments attached to the leaves were not removed, since brushing would have carried away leaf fragments. Analysis of the sediment fraction has shown that its organic matter content was low (about 5\%). Consequently, organic nitrogen, organic carbon, sugars, cellulose and lignin contents of this sediment fraction were also low $(<5 \%)$. Samples with great sediment fraction (organic content $<40 \%$ ) have not been used for analysis. Most of samples had a small sediment fraction (organic content $>60 \%$ ) and since organic matter constitutes 90 to $94 \%$ of the leaf weight in the three species, we can ignore the sediment part and equate the changes in the samples' organic fractions to those of the foliar matter for such samples. Sediment organic phosphorus contents $(0.05-0.10 \%)$ were in the same range as the leaves ones (A. Fabre, pers. commun.); then, organic phosphorus values may be overestimated and should be interpreted with caution (see Results and Discussion).

For each determination, a $250 \mathrm{mg}$-sample was used. The organic matter content was measured by loss on ignition $\left(2\right.$ hours at $\left.550^{\circ} \mathrm{C}\right)$. Total carbon was analysed by conductometrical determination of $\mathrm{CO}_{2}$ liberated after combustion (Carmhograph 


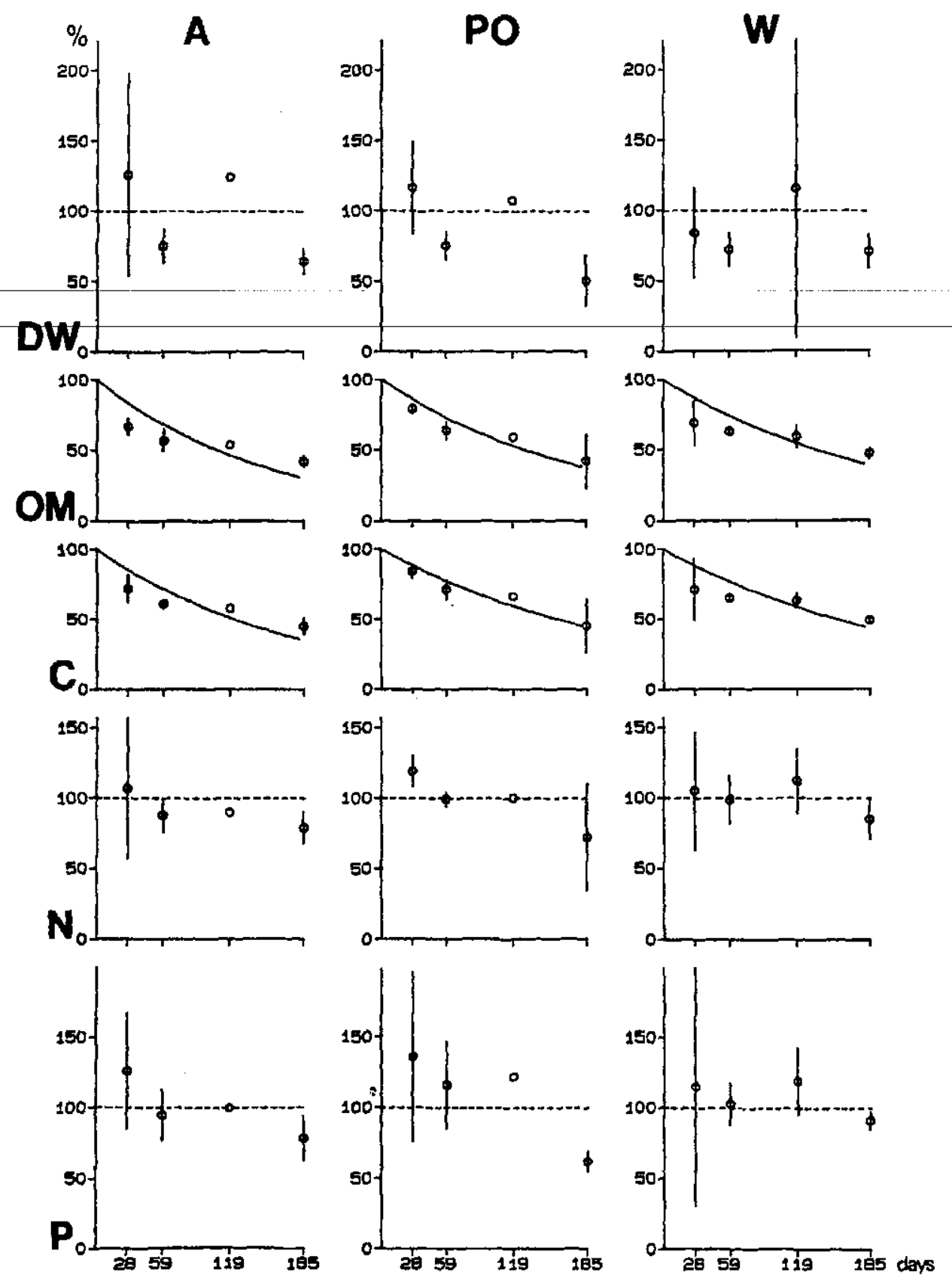

Fig. 1. Changes in dry weight (DW) and amounts of organic matter (OM), carbon (C), nitrogen (N) and phosphorus (P) for leaves of alder (A), poplar (PO) and willow (W) during decomposition, expressed as percent of original amount. The vertical lines represent the $95 \%$ confidence level around the mean of three samples, except for the 119th day for alder (1 sample) and poplar ( 2 samples). For OM and $C$, the fitted curve $y=e^{-k t}$ is drawn. Broken lines indicate no significant change from initial conditions. 
Wösthoff apparatus). Determination of total nitrogen was made with a Kjeldahl digestion followed by distillation and titration of the liberated ammonia (Büchi apparatus). Organic phosphorus was calculated by difference between total phosphorus and inorganic phosphorus, according to the method of Saunders \& Williams (1955) associated with the colorimetric method of Golterman et al. (1978). Polysaccharides were extracted with water (hydrosoluble) and $3 \mathrm{~N}$ sulphuric acid (not hydrosoluble) at $80^{\circ} \mathrm{C}$ according to Guckert's (1973) technique and analyzed by the phenol method of Dubois $e t$ al. (1956); the concentrations are given as glucoseequivalents. Cellulose and lignin were determined according to the method used by Goering \& Van Soest (1972), avoiding nitrogen analysis on the crude lignin residue; this technique does not distinguish between pure lignin and cutin ('acid-detergent lignin').

\section{Results}

The changes for dry weight, organic matter and total elements (in percentage of initial weight) are given in Fig. 1 and those for organic fractions in Fig. 2. If the values changed significantly, the data points were fitted to a negative exponential curve in order to obtain the reaction rate constant following Olson's (1963) formula: $W_{t}=W_{0} e^{-k t}$, where $W_{t}$ represents the weight remaining at time $t$ (days), $\mathrm{W}_{0}$ the initial weight and $\mathrm{k}$ the decomposition rate constant. A multiexponential model of the type $y=a e^{-k_{1} t}+(1-a) e^{-k_{2} t}$ is a better description of changes in polysaccharides amounts in our samples (Fig. 2).

Changes in dry weight fluctuated for the three species but not significantly. The peaks in the first month (alder, poplar) and in the fourth month corresponded to an increase of sediments, easily captured by leaves during winter or spring floods. This phenomenon has been reported for the River Thames by Mathews \& Kowalczewski (1969). Consequently, changes in this variable cannot be fitted to a simple model.

For organic matter, the data fit a negative exponential equation with variation coefficients ${ }^{b}$ ranging from 9 to $15 \%$, according to the species. During the 6 months of the experiment, decomposition of common alder was slightly more rapid $\left(k=0.00650\right.$ day $\left.^{-1}\right)$ than that of black poplar $\left(k=0.00536 \mathrm{day}^{-1}\right)$ and that of white willow $\left(k=0.00500 \mathrm{day}^{-1}\right)$, but these differences were not significant $(\mathrm{P}>0.05)$.

At the time of their fall, the leaves of these species had an organic carbon content of about $40 \%$ (Table 1). During decomposition, amounts of carbon changed comparably to that of organic matter: $\mathrm{k}=0.00568$ for alder, 0.00441 for poplar and 0.00453 for willow (Fig. 1). The initial nitrogen contents were low $(0.9 \%$ for poplar and $1.6 \%$ for willow), except for common alder $(2.2 \%)$ which had values similar to those of other species of the same genus. The organic nitrogen amount increased (not significantly) during the first month for the three species, decreased during the second month, then stabilized or increased again (willow) and finally decreased after six months to approximately $80 \%$ of the initial quantity. Initial values of $\mathrm{C} / \mathrm{N}$ ratios (Fig. 3) were very different for the three deciduous species: alder, rich in nitrogen had a low $\mathrm{C} / \mathrm{N}$ ratio of 19.3 whilst the $\mathrm{C} / \mathrm{N}$ ratios of willow and poplar were 25.4 and 41.9 respectively. The rapid decrease in $\mathrm{C} / \mathrm{N}$ noticed during the first month was followed by a very slow decrease until the sixth month. The amounts of organic phosphorus followed the same pattern as that of nitrogen, so the $\mathrm{N} / \mathrm{P}$ ratios for the three species remained constant during decomposition. Phosphorus enrichment was much greater than nitrogen one during the first month (more than $36 \%$ in poplar leaves) but sediment accumulation was also great in some samples

${ }^{b}$ Logarithmic equation $\log _{e}\left(w_{t} / w_{0}\right)=-k t+a$ is based on two coefficients $\mathbf{k}$ and $\mathbf{a}$. Authors generally use linear regression of logarithmic equation although Olson's model $W_{t} / W_{0}=e^{-k t}$ is only based on one coefficient (k). Olson's model is justified because decomposition curves always start from the point: $t=0$ and $W_{t} / W_{0}=1$. In other respects, logarithmic transformation of Olson's equation distorts the coefficient calculation because linear regression is based on $\mathrm{X}$ and $\mathrm{Y}$ arithmetic averages and arithmetic average of $\log _{e}\left(W_{t} / W_{0}\right)$ equals logarithm of $W_{t} / W_{0}$ geometric average. Least squares nonlinear models are then preferable. Since the model is non-linear, the standard deviation is asymptotic. The variation coefficient is the ratio of asymptotic standard deviation to $k$. This is the best estimation of the level of confidence around $k$.

In order to compare our results to others, decomposition rates have been also computed by linear regression of logarithmic equation. The coefficients are lower: $k=0.00272$ day $^{-1}$ for alder, $k=0.00375$ day $^{-1}$ for poplar and $k=0.00235$ day $^{-1}$ for willow (but intercept differs from zero). 

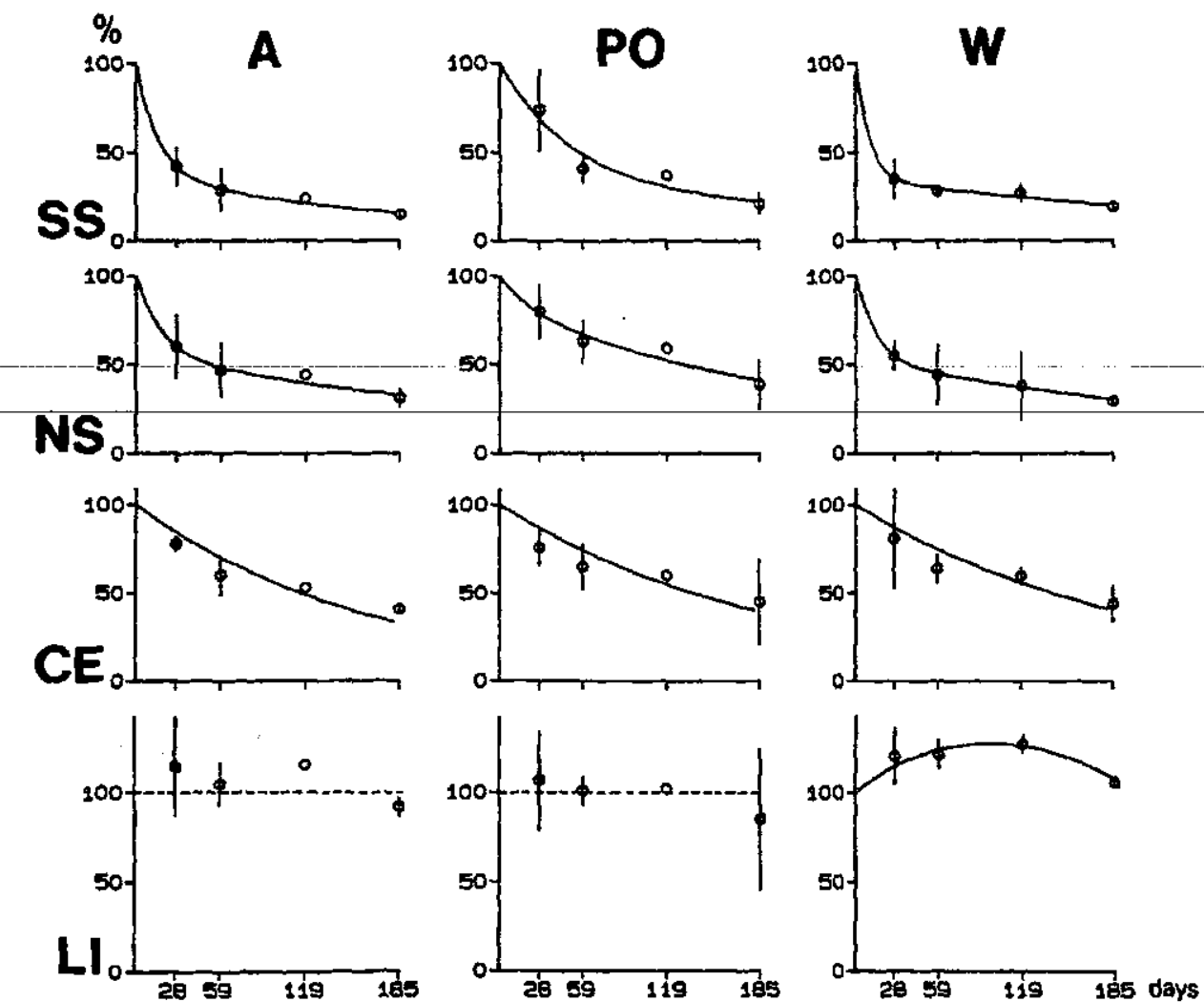

Fig. 2. Changes in amounts of water-soluble sugars (SS), 3N acid-soluble sugars (NS), cellulose (CE) and lignin (LI) for leaves of alder (A), poplar (PO) and willow (W) during decomposition, expressed as percent of original amount. For CE, an exponential fit is drawn; for SS and NS, a bi-exponential fit $y=a e^{-k_{1} t}+(1-a) e^{-k_{2} t}$ is drawn; for LI of $S$, a second degree polynomial fit $y=1+a t-b t^{2}$ is drawn.

Table 1. Original composition of alder, poplar and willow leaves (percent of dry weight with $95 \%$ confidence level).

\begin{tabular}{lclllll}
\hline Constituent & Alder & \multicolumn{2}{c}{ Poplar } & \multicolumn{2}{l}{ Willow } \\
\hline Carbon & 42.4 & \pm 0.2 & 39.0 & \pm 0.2 & 41.7 & \pm 0.3 \\
$\begin{array}{l}\text { Nitrogen } \\
\text { Organic } \\
\quad \text { phosphorus }\end{array}$ & $\mathbf{2 . 2 0} \pm 0.09$ & 0.93 & $0.063 \pm 0.002$ & $0.053 \pm 0.004$ & $0.073 \pm 0.002$ \\
$\begin{array}{l}\text { Water-soluble } \\
\quad \text { sugars }\end{array}$ & 6.2 & \pm 0.1 & 4.7 & \pm 0.1 & 5.9 & \pm 0.2 \\
$\begin{array}{l}\text { Acid-soluble } \\
\quad \text { sugars }\end{array}$ & 7.1 & \pm 0.2 & 8.1 & \pm 0.2 & 8.8 & \pm 0.7 \\
$\begin{array}{l}\text { Cellulose } \\
\text { Lignin }\end{array}$ & 15.0 & \pm 0.7 & 22.3 & \pm 0.5 & 18.5 & \pm 0.6 \\
& 12.4 & \pm 0.3 & 23.2 & \pm 1.3 & 20.0 & \pm 1.2 \\
\hline
\end{tabular}

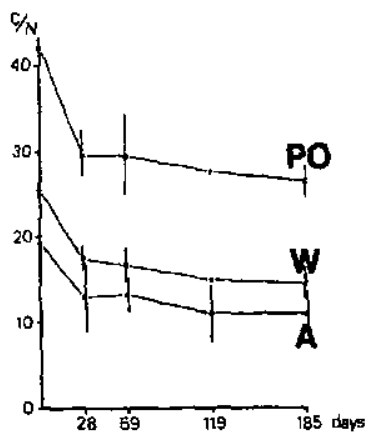

Fig. 3. Changes in $\mathrm{C} / \mathrm{N}$ weight ratios for leaves of alder (A), poplar (PO) and willow (W) during decomposition. 
after 1 and 4 months of exposure and a part of phosphorus amount could come from sediment. During the sixth month, the amount of phosphorus decreased below the initial level (62 to $91 \%$ ). This was due to the gradual disappearance of leaf material since the organic phosphorus contents of the three species during the six months of experimentation remained distinctly higher than the initial contents.

After_a-month, 2/3_of_the_willow's_water_soluble sugars disappeared (Fig. 2) while alder lost 58\% and poplar only $26 \%$; after six months, the residual percentages were in the same range for the three species (15 to $21 \%$ of the initial amounts). The decrease was less rapid for polysaccharides soluble in $3 \mathrm{~N}$ acid, and after six months of experimentation, these ranged from $29 \%$ (willow) to $39 \%$ (poplar) of the initial amounts.

The quantity of cellulose decreased rapidly during the six months and the kinetics were not significantly different from those for organic matter ( $k=0.00603 \mathrm{day}^{-1}$ for alder, $0.00504 \mathrm{day}^{-1}$ for poplar and 0.00492 day $^{-1}$ for willow, with variation coefficients from 8 to $11 \%$ ). The cellulose contents were thus relatively stable during decomposition. However, a slight difference was observed between the cellulose amount and the organic matter one in alder leaves after one month $(P<0.01)$; it corresponded to a relative accumulation of cellulose, which disappeared after two months of decomposition.

The amounts of lignin were higher than initial amounts, except for the sixth month for alder and poplar. Changes seem not to be significant for alder and poplar, but could be fitted to a second degree polynomial: $y=1+a t-b t^{2}$ for willow, this indicated a first phase of definite accumulation and a second phase of lignin stock decreaše (Fig. 2).

\section{Discussion}

\section{Organic matter}

The slowest decay of organic matter occurred in the samples on which the greatest quantities of sediments were deposited, although the organic content of the sediment is negligible. This fact, already reported by Reice (1974, 1977), Meyer (1980) and Tiwari \& Mishra (1983), suggests that large amounts of trapped sediments reduce the development of microorganisms and slow down decomposition.

The results show that these three species decompose according to comparable first order kinetics, with slightly different $\mathbf{k}$ coefficients. Values for the - same genera (Table 2) are very variable according to species but also because of the different experimental conditions (e.g.type of stream, temperature, water quality). The exposure technique also plays an important role (Benfield et al., 1979). From previous studies (Table 2), the minimum value for alder was obtained in a river and for willow in a pond; the maximum value for alder was found in a stream where exceptionally effective feeding by invertebrates occurred. When these extreme values are ignored, the coefficients are reduced to a narrower range and data from the present study, computed by either non-linear model or linear regression, constitute the lower limit for alder and willow. The rather low decomposition coefficients (linear regression) encountered in the Garonne rank the three species among 'Group III' with a k value lower than 0.005 day $^{-1}$ (Petersen \& Cummins, 1974).

\section{Total elements: $C, N, P$}

For six months, the percentages of carbon in alder, poplar and willow leaves remain close to $40 \%$. Anderson (1973) and Triska et al. (1975) also showed that carbon content was constant during decomposition.

The net nitrogen increase during the first month followed by a loss has also been observed in forests (Melillo \& Aber, 1984) and streams (Melillo et al., 1983). The initial immobilization of nitrogen probably corresponds to an import of nitrogenous compounds by the micoorganisms which colonize decomposing leaves. Aber \& Melillo (1980) have shown that decomposition dynamics of leaf and fine wood litter on forest soils could be described by inverse linear relationships between percentage of original mass remaining and nitrogen concentration in the residual material. The same relations have been observed for wood chips decomposition in a stream (Melillo et al., 1983). Organic matter and nitrogen dynamics during decomposition of the three leaf litter types in the Garonne river also conform to this model since correlation coeffi- 
Table 2. Decomposition rates for different species of the genera Alnus, Populus and Salix gathered from literature. For comparison purpose, values between brackets have been computed by linear regression.

\begin{tabular}{|c|c|c|c|c|c|c|}
\hline $\begin{array}{l}k \\
(\text { day }-1)\end{array}$ & $\begin{array}{l}\text { half life } \\
\text { (years) }\end{array}$ & $\begin{array}{l}95 \% \text { life } \\
\text { (years) }\end{array}$ & $\begin{array}{l}\text { duration exp. } \\
\text { (days) }\end{array}$ & Species & Author & Remarks \\
\hline 0.0012 & 1.64 & 7.11 & 210 & A. rugosa & $\begin{array}{l}\text { Kaushik \& } \\
\text { Hynes }(1971)^{1}\end{array}$ & river \\
\hline $\begin{array}{c}0.0065 \\
(0.0027)\end{array}$ & $\begin{array}{c}0.29 \\
(0.34)\end{array}$ & $\begin{array}{c}1.26 \\
(2.66)\end{array}$ & 185 & A. glutinosa & This study & \\
\hline 0.0075 & 0.25 & 1.09 & 365 & A. glutinosa & Triska $(1970)^{2}$ & $\begin{array}{l}\text { mesh size } \\
0.2 \mathrm{~mm}\end{array}$ \\
\hline 0.0124 & 0.15 & 0.66 & 250 & A. rubra & $\begin{array}{l}\text { Sedell et al. } \\
(1975)\end{array}$ & Watershed 10 \\
\hline 0.0168 & 0.11 & 0.49 & 250 & A. rubra & $\begin{array}{l}\text { Sedell et al. } \\
\text { (1975) }\end{array}$ & Mack Creek \\
\hline 0.0513 & 0.04 & 0.16 & 98 & A. tenuifolia & $\begin{array}{l}\text { Cowan et al. } \\
\text { (1983) }\end{array}$ & $\begin{array}{l}\text { subarctic } \\
\text { stream }\end{array}$ \\
\hline 0.0046 & 0.41 & 1.78 & - & P. tremuloides & $\begin{array}{l}\text { Petersen \& } \\
\text { Cummins (1974) }\end{array}$ & $\begin{array}{l}\text { average of } \\
2 \text { site and } \\
2 \text { seasons }\end{array}$ \\
\hline $\begin{array}{c}0.0054 \\
(0.0038)\end{array}$ & $\begin{array}{c}0.35 \\
(0.38)\end{array}$ & $\begin{array}{c}1.53 \\
(2.07)\end{array}$ & 185 & P. gr. nigra & This study & \\
\hline 0.0027 & 0.71 & 3.05 & 521 & S. sp. & $\begin{array}{l}\text { Hodkinson } \\
\text { (1975) }\end{array}$ & pond \\
\hline $\begin{array}{c}0.0050 \\
(0.0024)\end{array}$ & $\begin{array}{c}0.38 \\
(0.45)\end{array}$ & $\begin{array}{c}1.64 \\
(3.14)\end{array}$ & 185 & S. $a l b a$ & This study & \\
\hline 0.0059 & 0.32 & 1.39 & 273 & $S$. sp. & $\begin{array}{l}\text { Mathews \& } \\
\text { Kowalczewski } \\
(1969)^{1}\end{array}$ & $\begin{array}{l}\text { Thames } \\
\text { (mesh size } \\
0.27 \mathrm{~mm} \text { ) }\end{array}$ \\
\hline 0.0062 & 0.31 & 1.32 & 365 & $S$. nigro & Triska $(1970)^{2}$ & $\begin{array}{l}\text { mesh size } \\
0.2 \mathrm{~mm}\end{array}$ \\
\hline 0.0063 & 0.30 & 1.30 & 98 & $\begin{array}{l}\text { S. alexensis, } \\
\text { S. arbucolides }\end{array}$ & $\begin{array}{l}\text { Cowan et al. } \\
\text { (1983) }\end{array}$ & $\begin{array}{l}\text { subarctic } \\
\text { stream }\end{array}$ \\
\hline 0.0078 & 0.24 & 1.05 & - & S. lucida & $\begin{array}{l}\text { Petersen \& } \\
\text { Cummins (1974) }\end{array}$ & $\begin{array}{l}\text { average of } \\
2 \text { sites and } \\
2 \text { seasons }\end{array}$ \\
\hline 0.0168 & 0.11 & 0.49 & 273 & $S$. sp & $\begin{array}{l}\text { Mathews \& } \\
\text { Kowalczewski } \\
(1969)^{1}\end{array}$ & $\begin{array}{l}\text { Thames } \\
\text { (mesh size } \\
3 \mathrm{~mm} \text { ) }\end{array}$ \\
\hline
\end{tabular}

I From Hodkinson (1975).

2 From Petersen \& Cummins (1974).

cients are -0.98 for alder, -0.90 for poplar and -0.97 for willow.

Phosphorus and nitrogen contents expressed as percentage of organic matter generally increase during the experiment; nevertheless, the linear regressions for these changes are not significant. Meyer (1980) reported an increase in the content of phosphorus during decomposition; she observed an increase in the amount of phosphorus in sites with sedimentation (organic accumulation) and a decrease in the rapids. The site in the Garonne is comparable to her sedimentation zones: sediment deposits on leaves could be two to three times the weight of the leaves after four months of exposure. So organic phosphorus enrichment could come from sediment deposits.

The rapid drop of the $\mathrm{C} / \mathrm{N}$ ratio may improve the nutritive quality of the leaves. After six months, alder presents a stable $\mathrm{C} / \mathrm{N}$ ratio of 11 , very close to the effective mineralization optimum of 10 (Alexander, 1961; Mangenot \& Toutain, 1980). At this stage of decomposition, the decrease in poplar and 
especially willow $\mathrm{C} / \mathrm{N}$ ratios can also make the leaves more palatable (Russel-Hunter, 1970). Nitrogen frequently acts as a limiting factor for decomposition in small streams (Triska et al., 1975), but in a large river like Garonne nitrogen concentrations may be sufficient to sustain high decomposition rates.

\section{Organic fractions}

Sugars constitute an important fraction of leaf organic matter and are generally leached rapidly. Nykvist (1962) and Suberkropp et al. (1976) have established that water-soluble polysaccharides and polyphenols are the first products to be degraded, passing into the aqueous solution after a few hours of immersion. Our results show that poplar sugars are less easily leached from poplar leaves than from alder or willow leaves. However, disappearance of the soluble sugars was less rapid than that observed by Krumholz (1972) and by Suberkropp et al. (1976) for white oak and hickory leaves, in which 70 to $80 \%$ of the sugars are leached during the first two weeks. On the other hand, Tiwari \& Mishra (1983) have noticed slower kinetics for soluble sugars in teak leaves in India. Not only the quality of plant material but also the environmental factors (e.g. temperature, oxygenation) may be responsible for the differences.

Cellulose, hemicellulose and lignin are the major constituents of foliar tissue. The lignocelluloses represent 30 to $50 \%$ of the foliar organic matter of the three species studied. These percentages observed before decomposition are slightly higher than those given by Triska et al. (1975) and Suberkropp et al. (1976) for deciduous leaves. However, King \& Heath (1967) and Tiwari \& Mishra (1983) have found contents of the same magnitude or higher for other deciduous species. Mangenot \& Toutain (1980) explained this variability by the different determination techniques used by the various authors (most of these techniques tend to overestimate lignin concentrations).

The stability of the contents of cellulose and the slight difference observed between the changes in cellulose and organic matter during the two first months have already been pointed out by Suberkropp et al. (1976). In comparison with their results, the first step of cellulose relative accumulation for alder is longer than that for pignut hickory
(2 to 4 weeks) and shorter than that for white oak (12 to 16 weeks). During the first weeks, certain compounds (sugars, polyphenols) disappear, whereas cellulose is not degraded (slight increase of cellulose content).

The apparent increase in 'lignin' content agrees with the observed accumulations of nitrogen and phosphorus. However, there is probably a formation of products, reacting in the same manner as lignin from the other organic initial constituents (phenolic compounds) and fungal or bacterial products, as in soils (Mangenot \& Toutain, 1980). Suberkropp et al. (1976) showed the existence of nitrogenous compounds in the 'lignin' fraction during decomposition. This net accumulation of 'lignin' has also been demonstrated for soils by King \& Heath (1967) and for waters by Tiwari \& Mishra (1983).

Lignin and nitrogen contents are determinant factors for leaf decomposition kinetics in soils as well as in waters. Melillo et al. $(1982,1983)$ have shown the existence of a negative correlation between the ratio of initial lignin and nitrogen contents and decomposition rate of leaves or woody materials. The three species in the present study have variable lignin/ $\mathrm{N}$ ratios: 28 for black poplar, 14 for white willow and only 6 for alder. This latter value is probably close to the minimum for tree leaves, by reason of the high nitrogen content (Triska et al., 1975; Melillo et al., 1983). Nevertheless, the three species decomposition rates are very comparable and not negatively correlated with the lignin/ $\mathrm{N}$ ratios since the coefficient of determination for a linear relationship is 0.37 . We suppose the influence of other factors, especially environmental factors, to be more important in the Garonne river than lignin/ $\mathrm{N}$ ratios.

The changes of the following variables fit negative exponential equations $y=e^{-\mathrm{kt}}$ : organic matter, carbon, hydrosoluble sugars, diluted acidsoluble sugars and cellulose; the variation coefficients for these fits are within the range $8-18 \%$. The only significant differences between species are for polysaccharides (soluble in water or diluted acid) which disappear less rapidly in poplar than in alder and willow. The bi-exponential model for polysaccharides suggests that there are two types of compounds among simple sugars or two processes with different kinetics, such as leaching, abiotic fragmentation or degradation by microorganisms. 
During the six months of decomposition, changes in other constituents (nitrogen, phosphorus, lignin) were not significant, nor could they be fitted to a simple model (except for willow lignin).

In conclusion, common alder, black poplar and white willow leaves are decomposed following a comparable kinetic, despite their different initial ratios of $\mathrm{C} / \mathrm{N}$ and lignin/N. These species are not different in the decomposition rates of their constituents, except for that of sugars which is less rapid for poplar leaves. In these three species, simple sugars disappear very rapidly while cellulose contents remain constant. The results of the first months suggest that lignin, nitrogen and phosphorus present a net accumulation, probably related to microbial colonization and the formation of complex polyphenol-proteins of foliar or microbial origin.

\section{Acknowledgments}

I am grateful to Dr. H. L. Golterman and Dr. J. M. Elliott for their comments and suggestions on this paper.

\section{References}

Aber, J. D. \& J. M. Melillo, 1980. Litter decomposition: measuring state of decay and percent transfer into forest soils. Can. J. Bot. 58: $416-421$.

Alexander, M., 1961. Introduction to soil microbiology. John Wiley Sons, New York, $472 \mathrm{pp}$.

Anderson, J. M., 1973. The breakdown and decomposition of sweet chestnut (Castanaea sativa Mill.) and beech (Fagus sylvatica L.) leaf litter in two deciduous woodland soils. II. Changes in the carbon, hydrogen, nitrogen, and polyphenol content. Oecologia 12: 275-281.

Bärlocher, F. \& B. Kendrick, 1974. Dynamics of the fungal population on leaves in a stream. J. Ecol. 62: 761-791.

Benfield, E. F., D. S. Jones \& M. F. Patterson, 1977. Leaf pack processing in a pastureland stream. Oikos 29: 99-103.

Benfield, E. F., R. W. Paul Jr. \& J. R. Webster, 1979. Influence of exposure technique on leaf breakdown rates in streams. Oikos 33: 386-391.

Cowan, C. A., M. W. Oswood, C. A. Buttimore \& P. W. Flanagan, 1983. Processing and microinvertebrate colonization of detritus in an Alaskan subarctic stream. Holarct. Ecol, 6: $340 \rightarrow 348$.

Cummins, K. W, 1979. The natural stream ecosystem. The Ecology of regulated streams (Ed. by J. V. Ward \& J. A. Stanford), pp. 7-24. Plenum Press, New York.

Dubois, M., K. A. Gilles, J. K. Hamilton, P. A. Rebers \& F.
Smith, 1956. Colorimetric method for determination of sugars and related substances. Analyt. Chem. 28: 350-356.

Godshalk, G. L. \& R. G. Wetzel, 1978. Decomposition in the littoral zone of lakes. In: Freshwater wetlands, ecological processes and management potential (Ed. by R. E. Good, D. F. Whigham \& R. L. Simpson), pp. 131-144. Academic Press Ltd., New York.

Goering, H. K. \& P. J. van Soest, 1982. Forage fiber analyses (apparatus, reagents, procedures and applications). U.S. Department of Agriculture, Agriculture Handbook 379, 20 pp.

Golterman, H. L., R. S. Clymo \& M. A. M. Ohnstad, 1978. Method for physical and chemical analysis of fresh waters. IBP Handbook no 8, Blackwell Scientific Publieations - Ltd, 213 pp.

Guckert, A., 1973. Contribution à l'étude des polysaccharides dans les sols et leur rôle dans les mécanismes d'agrégation. Thèse d'Etat, Univ. Nancy I, 124 pp.

Hodkinson, I. D., 1975. Dry weight loss and chemical changes in vascular plant litter of terrestrial origin, occurring in a beaver pond ecosystem. J. Ecol. 63: 131-142.

Hynes, H. B. N., 1963. Imported organic matter and secondary productivity in streams. Proceedings of the XVIth International Congress of Zoology, Washington 4: 324-329.

Kaushik, N. K. \& H. B. N. Hynes, 1971. The fate of the dead leaves that fall into streams. Arch. Hydrobiol. 68: 465-515.

King, H. G. C. \& G. W. Heath, 1967. The chemical analysis of small samples of leaf material and the relationship between the disappearance and composition of leaves. Pedobiologia 7: $192-197$.

Krumholz, L. A., 1972. Degradation of riparian leaves and the recycling of nutrients in a stream ecosystem. University of Kentucky, Water Resources Institute, Research Report no 57, 36 pp.

Mangenot, F. \& F. Toutain, 1980. Les litières. Act. d'écol. forest (eds) P. Pesson, Gauthier-Villars, pp. 3-59.

Mathews, C. P.\& A. Kowalczewski, 1969. The disappearance of leaf litter and its contribution to production in the River Thames. J. Ecol. 57: \$43-552.

Melillo, J. M. \& J. D. Aber, 1984. Nutrient immobilization in decaying litter: an example of carbon-nutrient interactions. Trends in ecological research for the 1980s. (eds) J. H. Cooley \& F. B. Golley, pp. 193-215. Plenum Press, New York.

Melillo, J. M., J. D. Aber \& J. F. Muratore, 1982. Nitrogen and lignin control of hardwood leaf litter decomposition dynamics. Ecology 63: 621-626.

Melillo, J. M., R. J. Naiman, J. D. Aber \& K. N. Eshleman, 1983. The influence of substrate quality and stream size on wood decomposition dynamics. Oecologia 58: 281-285.

Meyer, J. L., 1980. Dynamics of phosphorus and organic matter during leaf decomposition in a forest stream. Oikos 34: 44-53.

Meyer, J. L. \& C. Johnson, 1983. The influence of elevated nitrate concentration on rate of leaf decomposition in a stream. Freshwat. Biol. 13: 177-183.

Minshall, G. W., 1967. Role of allochthonous detritus in the trophic structure of a woodland springbrook community. Ecology 48: 139-149.

Minshall, G. W., 1968. Community dynamics of the benthic fauna in a woodland springbrook. Hydrobiologia 32: 305-339.

Nykvist, N., 1962. Leaching and decomposition of litter. V. Ex 
periments on leaf litter of Alnus glutinosa, Fagus silvatica and Quencus robur. Oikos 13: 232-248.

Olson, J. S., 1963. Energy storage and the balance of producers and decomposers in ecological systems. Ecology 44: $322-330$.

Petersen, R. C. \& K. W. Cummins, 1974. Leaf processing in a woodland stream. Freshwat. Biol. 4: 343-368.

Reice, S. R, 1974. Environmental patchiness and the breakdown of leaf litter in a woodland stream. Ecology 55: 1271-1282.

Reice, S. R., 1977. The role of animal associations and current velocity in sediment-specific leaf litter decomposition. Oikos 29: $357-365$.

Reice, S. R., 1980. The role of substratum in benthic macroinvertebrate microdistribution and litter deeomposition in a-woodland stream. Ecology 61(3): 580-590.

Richard, Y. \& G. Moreau, 1982. Utilisation des feuilles de differentes especes d'arbres (peuplier, aulne, myrique) par la faune benthique dans les eaux oligotrophes du Bouclier canadien. Hydrobiologia 96: 77-89.

Russel-Hunter, W. D., 1970. Aquatic productivity: an introduction to some basic aspects of biological oceanography and limnology. McMillan, London, 306 pp.

Saunders, W. M. H. \& E. G. Williams, 1955. Observations on the determination of total organic phosphorus in soil. J. Soil Sci. 6: 254-267.

Sedell, J. R, F. J. Triska \& N. S. Triska, 1975. The processing of conifer and hardwood leaves in two coniferous forest streams. I. Weight loss and associated invertebrates. Verh. int. Ver. Limnol. 19: 1617-1627.

Suberkropp, K. \& J. M. Klug, 1976. Fungi and bacteria associat- ed with leaves during processing in a woodland stream. Ecology 57: $707-719$.

Suberkropp, K., G. L. Godshalk \& M. J. Klug, 1976. Changes in the chemical composition of leaves during processing in a woodland stream. Ecology 57: 720-727.

Tiwari, B. K.\& R. R. Mishra, 1983. Dry weight loss and changes in chemical composition of pine (Pinus kesiya Royle) needles and teak (Tectona grandis L.) leaves during processing in a freshwater lake. Hydrobiologia 98: 249-256.

Trémolières, M., 1979. De quelques effets hydrobiologiques de la genèse de phytomélanines (allomélanines) dans les maoérats aqueux de feuilles d'automne d'arbres forestiers. Thèse de 3 ème cycle, Univ. Strasbourg, 201 pp.

Triska, F. J, 1970. Seasonal distribution of aquatic hyphomycetes in relation to the disappearance of leaf litter from a woodland stream. Ph.D. thesis, University of Pittsburgh, 189 pp.

Triska, F. J., J. R. Sedell \& B. Buckley, 1975. The processing of conifer and hardwood leaves in two coniferous forest streams: II. Biochemical and nutrient changes. Verh. int. Ver. Limnol. 19: $1628-1639$.

Vannote, R. L., G. W. Minshall, K. W. Cummins, J. R. Sedell \& C. E. Cushing, 1980. The river continuum concept. Can, J. Fish. Aquat. Sci. 37: 130-137.

Willoughby, L. G., 1974. Decomposition of litter in freshwater. Biology of plant litter decomposition (Ed. by C. H. Dickinson \& G. J. F. Pugh), pp. 658-681. Academic Press, London. 